\title{
Industrial Policy, Credit Financing and Corporate Inventory
}

\author{
Ling-wen Kong Yan-xi Li \\ Faculty of Management and Economics, Dalian University of Technology \\ NO.2 Linggong Road, Ganjingzi District, Dalian 116024, China \\ E-mail: 13889657477@126.com
}

\begin{abstract}
As a way of government intervention in economy, industrial policy has an important impact on the decisionmaking behavior of enterprises.However, scholars have different views on the role of industrial policy. The article uses 33,154 A-share annual observation samples from 2000 to 2018 as the research object, examines the impact of industrial policies on corporate credit financing, and analyzes the economic consequences of industrial policies affecting credit financing from the perspective of inventory. The research conclusion shows that industrial policies can have an important impact on corporate credit financing. Compared with enterprises that are not supported by industrial policies, enterprises that are supported by industrial policies receive more credit financing; the convenience that industrial policies bring to corporate credit financing can encourage enterprises to expand their production scale, which in turn leads to a backlog of corporate inventories. The article expands the literature system of government macro-control that affects corporate behavior, and helps academics and practitioners to better understand the transmission mechanism of industrial policies affecting the real economy.
\end{abstract}

Keywords: Industrial Policy; Credit Financing; Inventory; Production

DOI: $10.7176 / \mathrm{EJBM} / 12-17-04$

Publication date:June 30th 2020

The "tangible hand" plays an important role in the market, and government macro-control measures such as industrial policy, monetary policy, and fiscal policy will affect the behavioral decisions of microenterprises(Friedman). As a commonly used macroeconomic policy, industrial policy is widely used in economic development by countries around the world. Now industrial policy has become an important way for the country to optimize the industrial structure and promote sustainable economic development, to a certain extent, it can enhance the spillover effect and solve market failures. China has implemented a total of 13 "five-year" plans, and industrial policies have played an important role in guiding and supporting the reform of the Chinese economic system. Industrial policy will also have an important impact on the financing behavior of micro-enterprises. It has been confirmed in the literature that industrial policies can ease the financing constraints of enterprises and help enterprises obtain more bank loans. Compared with western developed countries, China's financial system is not yet perfect, and it mainly relies on commercial banks. Due to the limited financing scale and high financing requirements of the stock market, Chinese companies rely more on the formal financial system dominated by banks. There is serious "ownership discrimination" and "scale discrimination" in the Chinese commercial banking system, which makes it more difficult for enterprises to obtain funds from formal financial channels. Industrial policies can provide credit facilities for the enterprises they support. This convenience is more reflected in the supply of bank credit funds. Byrd and Mizruchi found that industrial policies can help companies obtain more bank credit. After obtaining bank credit financing, companies often expand their production scale, which in turn may cause the company to experience inventory backlogs.

Based on this, this article takes A-share listed companies as research objects from 2000 to 2018, examines the impact of industrial policies on the sources of corporate debt financing, and further analyzes the impact of industrial policies on corporate inventories. This study found that industrial policy can have an important impact on corporate credit financing. Compared with enterprises that are not supported by industrial policies, enterprises that are supported by industrial policies receive more credit financing; the convenience that industrial policies bring to corporate credit financing can encourage enterprises to expand their production scale, which in turn leads to an inventory backlog.

\section{Theoretical analysis and research hypothesis}

China's financial market is underdeveloped, and it is more difficult for companies to obtain credit funds through banks, and then they turn to informal financial channels such as commercial credit and private loans to obtain funds for development. Literature has confirmed that commercial credit constitutes an important part of China's informal finance. The influence of industrial policy on the source of corporate debt financing is mainly reflected in the resource guidance effect. In order to achieve the expected industrial development goals, the government often adopts economic and administrative means to promote the implementation of industrial policies, such as credit policies, land policies, tax policies, and fiscal subsidy policies. China's financial system is dominated by 
large state-owned commercial banks, and government intervention has an important impact on the allocation of bank credit funds. The government guides the investment of credit funds through loan administrative approval, project approval, and allocates financial resources or loosens financial control for enterprises supported by industrial policies. In addition, the central bank will combine with the country's industrial policy to form a credit policy work opinion and issue it to various banking financial institutions to give full play to the credit policy guidance to make it serve the country's industrial structure adjustment strategy. Under the guidance of the central bank, banking financial institutions will adjust the focus of loans and the amount of loan changes to ensure that industrial policies support the funding needs of industry development. Based on this, this paper proposes the following research hypotheses:

H1:Compared with industrial enterprises that are not supported by industrial policies, there are more formal financial financings by industrial enterprises supported by industrial policies.

Enterprises supported by industrial policies are also more likely to obtain credit support, which in turn distort their technological choices, entry and exit decisions, and lead to resource mismatches between enterprises. China's economy is faced with many uncertainties. When enterprises are uncertain about the future direction of industry development, in order to reduce the impact of uncertainties on themselves, enterprises are more willing to respond to government calls for investment in industries supported by industrial policies. Government policies will further stimulate corporate investment and produce a "herding effect" of investment. Enterprises will reduce their consideration of market factors and rely more on industrial policies to make investment decisions. Industrial policy support will strengthen the market 's optimistic expectations, spur a "surge" of investment, and encourage companies to blindly expand production scale, resulting in overstocking, production capacity and the situation of reduced utilization. Based on this, this paper proposes the following research hypotheses:

$\mathrm{H} 2$ :Industrial policies supporting enterprises often expand the scale of production after obtaining credit financing, resulting in an inventory backlog.

\section{Research design}

2.1 Sample selection and data sources

This paper takes A-share listed companies as the research object from 2000 to 2018, excluding ST companies, companies with missing data, companies in the financial industry and companies with abnormal financial data, and finally obtains 33,154 annual observation samples of companies. Financial data and corporate governance data come from CSMAR. Industrial policy data was collected by the author by hand. In order to rule out the influence of extreme values, this paper carried out Winsorize shrinkage treatment of $1 \%$ and $99 \%$ for all continuous variables.

\subsection{Model design and variable definition}

In order to test the research hypothesis, this paper designed the following model:

(1) Among them, Financing is credit financing, specifically (cash received from bond issuance + cash received from borrowing-cash paid for debt repayment) / total liabilities; IPit is industrial policy support. This article determines whether an enterprise belongs to an industry supported by industrial policies based on the development plans of relevant industries in the five-year plan. If it belongs to, the industrial policy (IP) value is 1 , otherwise it is 0 . Referring to the research of Rodano et al. [7], the definition of control variables is shown in Table 1.

(2) Among them, Overprod is the overproduction of enterprises. Referring to the research of Roychowdhury [8], this paper uses the residual of the abnormal production model to measure overproduction.

(3) Among them, Inventory is enterprise inventory, specifically including inventory backlog and inventory turnover rate. Overstock, (semi-finished product + finished product) / total assets; Turnover, main business costs / inventory. 
Table 1 Variable definition and description

\begin{tabular}{|c|c|c|c|}
\hline $\begin{array}{l}\text { Variable } \\
\text { type }\end{array}$ & Variable name & $\begin{array}{l}\text { Variable } \\
\text { symbol }\end{array}$ & Variable definitions \\
\hline \multirow{3}{*}{$\begin{array}{l}\text { Explained } \\
\text { variable }\end{array}$} & Credit financing & Financing & $\begin{array}{l}\text { (Cash received for issuing bonds }+ \text { cash received for } \\
\text { obtaining loans-cash paid for debt repayment) / total } \\
\text { liabilities }\end{array}$ \\
\hline & Overproduction & Overprod & Abnormal production model residuals \\
\hline & Inventory backlog & Inventory & Including inventory backlog and inventory turnover \\
\hline \multicolumn{2}{|c|}{$\begin{array}{l}\text { Explanatory Industrial policy support } \\
\text { variables }\end{array}$} & $I P$ & $\begin{array}{l}\text { If the company is supported by the national five- } \\
\text { year plan, the value is } 1 \text {, otherwise it is } 0\end{array}$ \\
\hline \multirow{12}{*}{$\begin{array}{l}\text { Control } \\
\text { variable }\end{array}$} & Enterprise size & Size & Natural log of total assets \\
\hline & Profitability & $R O E$ & Roe \\
\hline & Growth ability & Growth & Operating income growth rate \\
\hline & $\begin{array}{l}\text { Asset mortgage } \\
\text { capacity }\end{array}$ & $F A$ & Fixed assets / total assets \\
\hline & Current ratio & Cur & Current assets / current liabilities \\
\hline & cash flow & $C F$ & Net cash flow from operating activities / total assets \\
\hline & Board size & Bsize & Natural logarithm of board members \\
\hline & Sole director ratio & $P I D$ & $\begin{array}{l}\text { Number of Independent Directors / Number of } \\
\text { Boards }\end{array}$ \\
\hline & Board of Supervisors & Ssize & Natural logarithm of the number of supervisors \\
\hline & Equity concentration & Topl & Shareholding ratio of the largest shareholder \\
\hline & year & Year & Controlling the year effect \\
\hline & industry & Ind & Control industry effects \\
\hline
\end{tabular}

\section{Empirical analysis}

3.1 Descriptive statistics

Table 2 is the descriptive statistical results of the main variables in this article. It can be seen from the results in the table that the average value of credit financing of enterprises is 0.016 . This shows that the problem of "difficult financing" for Chinese enterprises has always plagued the development of enterprises, and it is difficult for enterprises to obtain the funds needed for development from formal financial channels. The average value of industrial policy is 0.490 , which indicates that $49 \%$ of the listed companies are in industries supported by industrial policy, which also reflects that industrial policy has become a common method for the central government to regulate the economy.3.2 Variable definitions

Table 2 Descriptive statistical results of variables

\begin{tabular}{ccccccccc}
\hline Variable & $N$ & Mean & SD & Min & $p 25$ & Median & $p 75$ & Max \\
\hline Financing & 33154 & 0.016 & 0.209 & -0.933 & -0.044 & 0.003 & 0.117 & 0.518 \\
Overprod & 33154 & 0.168 & 0.080 & 0.000 & 0.019 & 0.044 & 0.389 & 0.656 \\
Inventory & 33154 & 0.147 & 0.133 & 0.017 & 0.059 & 0.116 & 0.189 & 0.690 \\
Turnover & 33154 & 5.068 & 0.347 & 0.004 & 1.848 & 3.587 & 6.955 & 22.386 \\
IP & 33154 & 0.490 & 0.500 & 0.000 & 0.000 & 0.000 & 1.000 & 1.000 \\
Size & 33154 & 21.718 & 1.218 & 18.977 & 20.848 & 21.578 & 22.399 & 25.721 \\
ROE & 33154 & 0.074 & 0.119 & -0.815 & 0.031 & 0.075 & 0.125 & 0.399 \\
Growth & 33154 & 0.201 & 0.513 & -0.681 & 0.000 & 0.107 & 0.285 & 3.734 \\
FA & 33154 & 0.241 & 0.172 & 0.002 & 0.108 & 0.208 & 0.343 & 0.747 \\
Cur & 33154 & 2.404 & 2.584 & 0.197 & 1.091 & 1.584 & 2.569 & 16.523 \\
CF & 33154 & 0.046 & 0.076 & -0.206 & 0.006 & 0.046 & 0.089 & 0.261 \\
Dsize & 33154 & 2.183 & 0.219 & 1.609 & 2.079 & 2.197 & 2.197 & 2.773 \\
PID & 33154 & 0.350 & 0.087 & 0.000 & 0.333 & 0.333 & 0.400 & 0.571 \\
Ssize & 33154 & 1.293 & 0.291 & 0.693 & 1.099 & 1.099 & 1.609 & 2.197 \\
Top1 & 33154 & 0.327 & 0.181 & -0.044 & 0.202 & 0.311 & 0.453 & 0.750 \\
\hline
\end{tabular}

Figure 1 shows the distribution characteristics of the sample industry, from which you can intuitively observe 
the distribution characteristics of the sample companies in different industries. Among them, white represents samples without industrial policy support, and black represents samples with industrial policy support. It can be found from the figure that the most supported by the national industrial policy is the manufacturing industry (industry code C), with a total of 9562 observation samples; In the information transmission, software and information technology service industry (industry code I), 1,645 observation samples are supported by national industrial policies, which is inseparable from the new generation of information technology industry development policies that China has been promoting at this stage. There are 1423 observation samples in the real estate industry (industry code K) supported by national industrial policies. This is mainly due to China's positioning of the real estate industry as a pillar industry of the national economy in 2003. It has only gradually faded the status of the pillar industry of the real estate industry in recent years. There are 1141 observation samples in the transportation industry (industry code G) supported by the national industrial policy. Investment in the "iron public plane" is the most common way for the country to invest in infrastructure construction. Therefore, the transportation industry is supported by the national industrial policy.

Figure 1 Industry distribution of the sample

\begin{tabular}{ccccccc}
\hline \multirow{2}{*}{ Variable } & \multicolumn{2}{c}{$\mathrm{IP}=0$} & \multicolumn{2}{c}{$\mathrm{IP}=1$} & T test & \multirow{2}{*}{ Wilcoxon $Z$} \\
\hline Financing & 0.015 & 0.004 & 0.017 & 0.005 & $-0.002^{* * *}$ & $-0 . .001^{* * *}$ \\
Overprod & 0.067 & 0.044 & 0.070 & 0.045 & $-0.003^{* * *}$ & $-0.001^{* * *}$ \\
Inventory & 0.145 & 0.108 & 0.148 & 0.124 & $-0.003^{* * *}$ & $-0.016^{* * *}$ \\
Turnover & 11.855 & 3.772 & 10.312 & 3.414 & $1.543^{* * *}$ & $0.358^{* * *}$ \\
Cost & 0.054 & 0.045 & 0.050 & 0.044 & $0.004^{* *}$ & $0.001^{* * *}$ \\
Size & 21.752 & 21.603 & 21.683 & 21.553 & $0.069^{* * *}$ & $0.050^{* * *}$ \\
ROE & 0.077 & 0.074 & 0.071 & 0.076 & $0.006^{* * *}$ & $-0.002^{*}$ \\
Growth & 0.194 & 0.102 & 0.208 & 0.112 & $-0.014^{* *}$ & $-0.010^{* * *}$ \\
FA & 0.241 & 0.212 & 0.241 & 0.204 & 0.000 & $0.008^{* * *}$ \\
Cur & 2.277 & 1.56 & 2.535 & 1.615 & $-0.258^{* * *}$ & $-0.055^{* * *}$ \\
CF & 0.045 & 0.044 & 0.047 & 0.047 & $-0.002^{* *}$ & $-0.003^{* * *}$ \\
Dize & 2.179 & 2.197 & 2.187 & 2.197 & $-0.008^{* * *}$ & $0.000^{* * *}$ \\
PID & 0.353 & 0.333 & 0.348 & 0.333 & $0.005^{* * *}$ & $0.000^{* * *}$ \\
Ssize & 1.291 & 1.099 & 1.296 & 1.099 & -0.005 & 0.000 \\
Top1 & 0.324 & 0.308 & 0.330 & 0.316 & $-0.006^{* * *}$ & $-0.008^{* * *}$
\end{tabular}

Notes: $* \mathrm{p}<0.10, * * \mathrm{p}<0.05, * * * \mathrm{p}<0.01$

\subsection{Industrial policy and corporate credit financing}

Table 4 shows the regression results of industrial policies affecting corporate credit financing. It can be seen from the table that the regression coefficient of IP and Financing is 0.009 , which is significantly positive at the level of 0.01 . This shows that, compared with the enterprises without industrial policy support, the credit financing level of the enterprises supported by industrial policy is higher, which basically confirms H1 of this article. Considering that there may be a certain lag effect of industrial policy affecting corporate credit financing, this paper also examines the impact of industrial policy on $\mathrm{T}+1$ corporate credit financing, and the empirical results are consistent with the above. Due to space limitations, the regression results of the control variables have not been analyzed in detail. 
Table 4 Regression results of industrial policies and sources of debt financing

\begin{tabular}{|c|c|c|}
\hline Variable & Financing $_{i t}$ & Financing $_{i, t+1}$ \\
\hline \multirow[t]{2}{*}{$I P_{i t}$} & $0.009^{* * *}$ & $0.004^{*}$ \\
\hline & $(4.016)$ & $(1.845)$ \\
\hline \multirow[t]{2}{*}{ Size $_{i t}$} & $0.015^{* * *}$ & $0.007^{* * *}$ \\
\hline & (15.233) & $(6.468)$ \\
\hline \multirow[t]{2}{*}{$R O E_{i t}$} & $0.131^{* * *}$ & $0.205^{* * *}$ \\
\hline & (11.864) & (13.892) \\
\hline \multirow[t]{2}{*}{ Growth $_{i t}$} & $0.020^{* * *}$ & $0.022^{* * *}$ \\
\hline & $(7.647)$ & (9.219) \\
\hline \multirow[t]{2}{*}{$F A_{i t}$} & $-0.028^{* * *}$ & 0.012 \\
\hline & $(-3.563)$ & (1.499) \\
\hline \multirow[t]{2}{*}{ Cur $_{i t}$} & $-0.017^{* * *}$ & $0.002^{* * *}$ \\
\hline & $(-21.946)$ & $(5.031)$ \\
\hline \multirow[t]{2}{*}{$C F_{i t}$} & $-0.661^{* * *}$ & $-0.228^{* * *}$ \\
\hline & $(-32.262)$ & $(-12.086)$ \\
\hline \multirow[t]{2}{*}{$B_{s i z e}{ }_{i t}$} & $-0.010^{*}$ & $0.011^{*}$ \\
\hline & $(-1.698)$ & $(1.717)$ \\
\hline \multirow[t]{2}{*}{$P I D_{i t}$} & $-0.063^{* * *}$ & $-0.031^{*}$ \\
\hline & $(-4.468)$ & $(-1.909)$ \\
\hline \multirow[t]{2}{*}{ Ssize $_{i t}$} & $-0.011^{* * *}$ & -0.003 \\
\hline & $(-2.665)$ & $(-0.666)$ \\
\hline \multirow[t]{2}{*}{ Top $1_{i t}$} & 0.009 & 0.006 \\
\hline & (1.543) & $(0.813)$ \\
\hline \multirow[t]{2}{*}{ Constant } & $0.015^{* * *}$ & $-0.152^{* * *}$ \\
\hline & (15.233) & $(-6.366)$ \\
\hline Year/Ind & Control & Control \\
\hline $\operatorname{Adj}-R^{2}$ & 0.113 & 0.091 \\
\hline$N$ & 33154 & 28994 \\
\hline
\end{tabular}

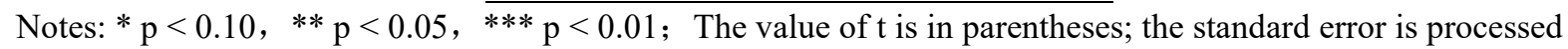
by the double cluster at the company level.

\section{Will industrial policies cause companies to overproduce?}

In order to test the timeliness of the impact of credit support brought by industrial policy support on the production behavior of enterprises, we report the regression results from period $\mathrm{T}$ to period $\mathrm{T}+3$. It can be found that the regression coefficients of IP $\times$ Financing are $0.063,0.082,0.075$, and 0.057 from the $\mathrm{T}$ period to the $\mathrm{T}+3$ period; and are significant at the $5 \%$ level in the $\mathrm{T}$ period and the $\mathrm{T}+3$ period; both in $\mathrm{T}+1$ period and $\mathrm{T}+2$ period were significant at $1 \%$ level. Among them, the regression coefficient is the largest in $T+1$ period, followed by $T+2$ period. The regression results show that industrial policy support has brought more credit support to the company and also promoted the increase of the company's excessive production behavior. This effect is particularly significant from the $\mathrm{T}$ period to the $\mathrm{T}+2$ period, and is most significant in the $\mathrm{T}+1$ period. Therefore, the positive correlation between industrial policy and enterprises' overproduction is time-sensitive. The research conclusion of this paper also has the following economic significance: Compared with enterprises that are not supported by industrial policies, enterprises that are supported by industrial policies will receive more credit support. And the incremental credit support brought by this industrial policy will increase the cash held by the company, making the company prone to overinvestment, which will lead to an increase in the level of overproduction of companies supported by industrial policy than those that are not $8.2 \%$. The regression results verify the H1 of this article. 
Table 5 Regression results based on the perspective of overproduction

\begin{tabular}{|c|c|c|c|c|}
\hline Variable & Overprod $_{i t}$ & Overprod $_{i, t+1}$ & Overprod $_{i, t+2}$ & Overprod $_{i, t+3}$ \\
\hline \multirow{2}{*}{$I P_{i t}$} & 0.012 & $0.012^{*}$ & 0.010 & 0.011 \\
\hline & $(1.246)$ & (1.898) & $(0.136)$ & $(0.657)$ \\
\hline \multirow[t]{2}{*}{$I P_{i t} \times$ Financing $_{i t}$} & $0.063^{* *}$ & $0.082^{* * *}$ & $0.075^{* * *}$ & $0.057^{* *}$ \\
\hline & (1.997) & $(5.517)$ & (3.208) & $(2.155)$ \\
\hline \multirow[t]{2}{*}{ Financing $_{i t}$} & 0.006 & $0.022^{* * *}$ & $0.009^{* * *}$ & $0.003^{* *}$ \\
\hline & (1.618) & $(3.710)$ & (3.609) & $(2.063)$ \\
\hline \multirow[t]{2}{*}{ Size $_{i t}$} & $-0.005^{* * *}$ & $-0.010^{* * *}$ & $-0.008^{* * *}$ & $-0.008^{* * *}$ \\
\hline & $(-6.903)$ & $(-10.798)$ & $(-11.103)$ & $(-10.681)$ \\
\hline \multirow{2}{*}{$R O E_{i t}$} & $0.050^{* * *}$ & $0.036^{* * *}$ & $0.022^{* * *}$ & 0.004 \\
\hline & (4.434) & $(4.115)$ & (3.605) & $(0.451)$ \\
\hline \multirow{2}{*}{ Growth $_{\text {it }}$} & $0.039^{* * *}$ & 0.002 & $0.004^{* * *}$ & 0.001 \\
\hline & $(8.455)$ & $(1.601)$ & $(2.932)$ & $(0.538)$ \\
\hline \multirow[t]{2}{*}{$F A_{i t}$} & $-0.049^{* * *}$ & $-0.025^{* * *}$ & $-0.013^{* *}$ & $-0.010^{* *}$ \\
\hline & $(-8.209)$ & $(-5.005)$ & $(-2.538)$ & $(-2.117)$ \\
\hline \multirow[t]{2}{*}{$\mathrm{Cur}_{i t}$} & $0.001^{* * *}$ & $0.002^{* * *}$ & $0.001^{* * *}$ & $0.001^{* *}$ \\
\hline & (3.494) & $(6.040)$ & $(3.403)$ & $(2.329)$ \\
\hline \multirow[t]{2}{*}{$C F_{i t}$} & $-0.151^{* * *}$ & -0.009 & 0.010 & 0.011 \\
\hline & $(-8.479)$ & $(-0.683)$ & (1.118) & $(1.220)$ \\
\hline \multirow{2}{*}{ Bsize $_{i t}$} & -0.001 & -0.001 & -0.001 & -0.002 \\
\hline & $(-0.299)$ & $(-0.083)$ & $(-0.309)$ & $(-0.692)$ \\
\hline \multirow[t]{2}{*}{$P I D_{i t}$} & $0.028^{* * *}$ & -0.002 & 0.008 & 0.004 \\
\hline & $(3.461)$ & $(-0.041)$ & $(0.821)$ & $(0.449)$ \\
\hline \multirow[t]{2}{*}{ Ssize $_{i t}$} & -0.004 & -0.003 & -0.004 & -0.004 \\
\hline & $(-1.261)$ & $(-1.125)$ & $(-1.568)$ & $(-1.547)$ \\
\hline \multirow[t]{2}{*}{$\operatorname{Top}_{i t}$} & $0.028^{* * *}$ & 0.006 & 0.004 & 0.001 \\
\hline & $(4.829)$ & $(1.484)$ & $(0.085)$ & $(0.332)$ \\
\hline \multirow{2}{*}{ Constant } & 0.187 & 0.277 & 0.237 & 0.223 \\
\hline & $(0.812)$ & $(0.001)$ & $(0.016)$ & $(0.002)$ \\
\hline Year/Ind & Control & Control & Control & Control \\
\hline $\operatorname{Adj}-R^{2}$ & 0.147 & 0.115 & 0.139 & 0.157 \\
\hline$N$ & 33154 & 28995 & 25051 & 21604 \\
\hline
\end{tabular}

\section{Will industrial policies cause companies to overproduce?}

Consistent with the foregoing, we report the regression results from period $\mathrm{T}$ to period $\mathrm{T}+3$. It can be found that the regression coefficients of IP $\times$ Financing are $0.035,0.046,0.038$, and 0.031 from the $\mathrm{T}$ period to the $\mathrm{T}+3$ period, respectively, and they are significant at $1 \%$ from the $\mathrm{T}$ period to the $\mathrm{T}+3$ period. Among them, the regression coefficient is the largest in $\mathrm{T}+1$ period, followed by $\mathrm{T}+2$ period. The regression results show that industrial policy support has brought more credit support to the company and increased the company's inventory, which has the greatest impact during the $T+1$ period. The research conclusions of this paper also have the following economic significance: Compared with enterprises not supported by industrial policies, enterprises supported by industrial policies will receive more credit support. The incremental credit support brought by this industrial policy will increase the cash held by the enterprise, which further promotes the company's overinvestment and over-production, which in turn causes an increase in the inventory backlog by $4.6 \%$. The regression results fully show that industrial policy support has brought credit support to enterprises while also increasing the possibility of inventory backlog. 
Table 6 Regression results based on the perspective of inventory backlog

\begin{tabular}{|c|c|c|c|c|}
\hline Variable & Inventory $_{i t}$ & Inventory $_{i, t+1}$ & Inventory $_{i, t+2}$ & Inventory $_{i, t+3}$ \\
\hline \multirow[t]{2}{*}{$I P_{i t}$} & $0.017^{* * *}$ & $0.018^{* * *}$ & $0.018^{* * *}$ & $0.019^{* * *}$ \\
\hline & $(6.414)$ & $(7.414)$ & $(7.342)$ & $(5.856)$ \\
\hline \multirow[t]{2}{*}{$I P_{i t} \times$ Financing $_{i t}$} & $0.035^{* * *}$ & $0.046^{* * *}$ & $0.038^{* * *}$ & $0.031^{* * *}$ \\
\hline & $(3.646)$ & $(4.974)$ & (4.179) & $(2.956)$ \\
\hline \multirow[t]{2}{*}{ Financing $_{i t}$} & $0.033^{* * *}$ & $0.040^{* * *}$ & $0.041^{* * *}$ & $0.028^{* * *}$ \\
\hline & $(7.182)$ & (9.393) & $(9.830)$ & $(5.599)$ \\
\hline \multirow[t]{2}{*}{ Size $_{i t}$} & $0.004^{* *}$ & $0.004^{* * *}$ & $0.005^{* * *}$ & $0.003^{* *}$ \\
\hline & $(2.557)$ & $(3.011)$ & $(3.144)$ & $(2.159)$ \\
\hline \multirow[t]{2}{*}{$R O E_{i t}$} & 0.018 & $0.030^{* * *}$ & $0.041^{* * *}$ & 0.011 \\
\hline & $(1.434)$ & $(2.593)$ & $(3.476)$ & $(0.831)$ \\
\hline \multirow[t]{2}{*}{ Growth $_{i t}$} & 0.001 & $0.003^{*}$ & $0.003^{*}$ & $0.004^{* *}$ \\
\hline & $(0.252)$ & $(1.711)$ & $(1.768)$ & $(2.204)$ \\
\hline \multirow[t]{2}{*}{$F A_{i t}$} & $-0.177^{* * *}$ & $-0.183^{* * *}$ & $-0.190^{* * *}$ & $-0.171^{* * *}$ \\
\hline & $(-16.300)$ & $(-17.413)$ & $(-17.943)$ & $(-14.895)$ \\
\hline \multirow[t]{2}{*}{$\mathrm{Cur}_{i t}$} & $-0.006^{* * *}$ & $-0.007^{* * *}$ & $-0.008^{* * *}$ & $-0.005^{* * *}$ \\
\hline & $(-13.375)$ & $(-15.422)$ & $(-18.256)$ & $(-11.068)$ \\
\hline \multirow[t]{2}{*}{$C F_{i t}$} & $-0.208^{* * *}$ & $-0.218^{* * *}$ & $-0.217^{* * *}$ & $-0.206^{* * *}$ \\
\hline & $(-13.178)$ & $(-14.766)$ & $(-15.267)$ & $(-12.060)$ \\
\hline \multirow[t]{2}{*}{ Bsize $_{i t}$} & 0.002 & 0.001 & -0.012 & -0.003 \\
\hline & $(0.049)$ & $(0.165)$ & $(-0.056)$ & $(-0.045)$ \\
\hline \multirow[t]{2}{*}{$P I D_{i t}$} & -0.028 & -0.019 & -0.024 & -0.023 \\
\hline & $(-1.215)$ & $(-0.895)$ & $(-1.085)$ & $(-0.961)$ \\
\hline \multirow[t]{2}{*}{ Ssize $_{i t}$} & 0.002 & 0.001 & -0.004 & -0.001 \\
\hline & $(0.036)$ & $(0.131)$ & $(-0.006)$ & $(-0.085)$ \\
\hline \multirow[t]{2}{*}{ Top $1_{i t}$} & $0.029^{* * *}$ & $0.030^{* * *}$ & $0.033^{* * *}$ & $0.026^{* *}$ \\
\hline & $(2.718)$ & $(3.073)$ & $(3.357)$ & $(2.313)$ \\
\hline \multirow[t]{2}{*}{ Constant } & $0.101^{*}$ & 0.039 & 0.054 & $0.136^{* *}$ \\
\hline & $(1.774)$ & (1.007) & $(1.345)$ & $(2.250)$ \\
\hline Year/Ind & Control & Control & Control & Control \\
\hline$A d j-R^{2}$ & 0.377 & 0.380 & 0.378 & 0.377 \\
\hline$N$ & 33154 & 28995 & 25051 & 21604 \\
\hline
\end{tabular}

This paper also examines the resource allocation efficiency of credit support brought by industrial policy support to enterprises from the perspective of inventory turnover rate. The specific results are shown in Table 7. From the regression results, it can be found that the regression coefficients of IP $\times$ Financing are $-0.239,-0.269$, $0.248,-0.107$ from the $\mathrm{T}$ period to the $\mathrm{T}+3$ period. And it is significant at the level of $1 \%$. Among them, the regression coefficient is the smallest in $\mathrm{T}+1$ period, followed by $\mathrm{T}+2$ period. This shows that industrial policy support has brought more credit support to enterprises and reduced the company's inventory turnover rate. This effect is most obvious in the $\mathrm{T}+1$ period. The research conclusion of this paper also has the following economic significance: Compared with the enterprises not supported by industrial policies, the inventory turnover rate of enterprises supported by industrial policies has decreased by about $26.9 \%$. The H2 of this article was verified. 
Table 7 Regression results based on the perspective of inventory turnover

\begin{tabular}{|c|c|c|c|c|}
\hline Variable & Turnover $_{i t}$ & Turnover $_{i, t+1}$ & Turnover $_{i, t+2}$ & Turnover $_{i, t+3}$ \\
\hline \multirow[t]{2}{*}{$I P_{i t}$} & $-2.537^{* * *}$ & $-6.769^{* * *}$ & $-6.024^{* * *}$ & -1.294 \\
\hline & $(-3.062)$ & $(-13.869)$ & $(-12.808)$ & $(-1.265)$ \\
\hline \multirow[t]{2}{*}{$I P_{i t} \times$ Financing $_{i t}$} & $-0.239^{* * *}$ & $-0.269^{* * *}$ & $-0.248^{* * *}$ & $-0.107^{* * *}$ \\
\hline & $(-10.155)$ & $(-19.177)$ & $(-17.969)$ & $(-3.193)$ \\
\hline \multirow[t]{2}{*}{ Financing $_{i t}$} & $-11.088^{* * *}$ & $-22.570^{* * *}$ & $-21.074^{* * *}$ & -1.314 \\
\hline & $(-6.070)$ & $(-13.055)$ & $(-12.713)$ & $(-0.571)$ \\
\hline \multirow[t]{2}{*}{ Size $_{i t}$} & 0.066 & $0.700^{* * *}$ & $0.574^{* *}$ & -0.167 \\
\hline & $(0.148)$ & (2.613) & $(2.285)$ & $(-0.302)$ \\
\hline \multirow[t]{2}{*}{$R O E_{i t}$} & $13.568^{* * *}$ & $15.770^{* * *}$ & $14.593^{* * *}$ & -0.745 \\
\hline & $(4.110)$ & $(6.136)$ & $(6.075)$ & $(-0.186)$ \\
\hline \multirow[t]{2}{*}{ Growth $_{\text {it }}$} & $2.099^{* * *}$ & $0.976^{* *}$ & $0.739^{*}$ & $1.881^{* *}$ \\
\hline & (3.135) & (2.264) & (1.887) & (2.368) \\
\hline \multirow[t]{2}{*}{$F A_{i t}$} & $12.295^{* * *}$ & $16.484^{* * *}$ & $16.122^{* * *}$ & $12.021^{* * *}$ \\
\hline & (3.118) & (7.104) & $(7.526)$ & $(2.760)$ \\
\hline \multirow[t]{2}{*}{ Cur $_{i t}$} & $1.117^{* * *}$ & $1.149^{* * *}$ & $1.165^{* * *}$ & $0.505^{* *}$ \\
\hline & (5.296) & $(6.774)$ & $(6.901)$ & $(2.272)$ \\
\hline \multirow[t]{2}{*}{$C F_{i t}$} & -1.588 & $-19.764^{* * *}$ & $-19.666^{* * *}$ & $16.876^{* * *}$ \\
\hline & $(-0.298)$ & $(-4.745)$ & $(-5.016)$ & $(3.251)$ \\
\hline \multirow[t]{2}{*}{ Bsize $_{i t}$} & -1.991 & -1.986 & -2.233 & -2.258 \\
\hline & $(-0.884)$ & $(-1.244)$ & $(-1.499)$ & $(-0.853)$ \\
\hline \multirow[t]{2}{*}{$P I D_{i t}$} & $11.547^{*}$ & 5.900 & 3.069 & 6.439 \\
\hline & $(1.732)$ & $(1.302)$ & $(0.732)$ & $(0.807)$ \\
\hline \multirow[t]{2}{*}{ Ssize $_{i t}$} & 1.372 & $1.896^{*}$ & 1.203 & 0.243 \\
\hline & $(0.777)$ & (1.652) & (1.113) & $(0.121)$ \\
\hline \multirow[t]{2}{*}{ Topl $_{i t}$} & $4.960^{*}$ & 2.076 & 1.923 & 2.375 \\
\hline & (1.734) & $(1.241)$ & $(1.222)$ & $(0.684)$ \\
\hline \multirow[t]{2}{*}{ Constant } & 11.194 & $14.411^{* * *}$ & -4.117 & $15.445^{* *}$ \\
\hline & $(0.823)$ & $(3.010)$ & $(-0.902)$ & $(2.395)$ \\
\hline Year/Ind & Control & Control & Control & Control \\
\hline $\operatorname{Adj}-R^{2}$ & 0.141 & 0.218 & 0.206 & 0.152 \\
\hline$N$ & 33154 & 28995 & 25051 & 21604 \\
\hline
\end{tabular}

\section{Conclusion}

Macro-control is an important means for the government to optimize the allocation of resources,and it can help overcome market failures and make up for the shortcomings and deficiencies of the market mechanism. As an important means of government macro-control, industrial policies are widely used by countries around the world in economic development and have played a huge role in promoting them. How industrial policies affect microenterprise behavior has become a hot topic of concern in domestic and foreign academic circles. This study found that industrial policy can have an important impact on corporate credit financing. Compared with enterprises that are not supported by industrial policies, enterprises that are supported by industrial policies receive more credit financing; the convenience that industrial policies bring to corporate credit financing can encourage enterprises to expand their production scale, which in turn leads to an inventory backlog.In the future, scholars can try to investigate the differences of industrial policies in different countries. The research based on cross-border comparison can help the academic community to understand whether the industrial policy will be affected by the national institutional background. The discussion of this problem will help us to identify the mechanism of industrial policy.

\section{References}

Friedman, M. (1968). The Role of Monetary Policy. American Economic Review, 58(1): 1-17. 
Murphy, K.,Shleifer, A., Vishny, R. W.(1989). Industrialization and the big push. Journal of Political Economy, (97):1003-1026.

Wallsten, S. J.(2000).The effects of government industry R\&D programs on private R\&D: The case of the small business innovation research program.RAND Journal of Economics,(31):82-100.

Czarnitzki, D., Hottenrot, H. (2014).Financing constraints for industrial innovation: What do we know?. Review of Business and Economic Literature,(1):21-39.

Byrd, D. T., Mizruchi, M. S. (2005).Bankers on the board and the debt ratio of firms. Journal of Corporate Finance, 11(1):129-173.

Allen, F., Qian, J., Qian, M. (2005).Law, finance, and economic growth in China. Journal of Financial Economics, 77(1):57-116.

Klenow, H.J. (2009).Misallocation and manufacturing TFP in China and India. Quarterly Journal of Economics, (4):1403-1448.

Rodano, G., Serrano-velarde, N., Tarantino, E . (2016).Bankruptcy law and bank financing. Journal of Financial Economics, 120(2):363-382.

Roychowdhury, S. (2006).Earnings management through real activities manipulation. Journal of Accounting \& Economics, 42(3):335-370. 